\title{
Some Problems Connected with Examining Silence and Being Quiet while Interaction Rituals and Everyday Conversations
}

\begin{abstract}
Both conversational analysis and examination of interactive rituals concentrate on distinguishing the structure of everyday conversations and language definition of social situations of the social interaction participants. It seems though that the researchers devote too little attention to the development of methods and techniques of research, detailed analysis of the transcription of keeping quiet by the participants of the social interaction. The aim of the article is to focus attention on the problems of treating meaningful silence by researchers as a speech, the tool and means of social actor expression, as important as other parts of speech. Some social contexts and conditions of silence were shown within different situations and worlds. The causes, results and myths of employees silence were presented. Silence was analysed in the context of existing in social worlds orders as a sign of crystallization and formation of statuses and micro social processes with special attention on the role of silence of social actors. The text uses some experience of language researchers, sociologists of language and emotion.
\end{abstract}

\section{Keywords:}

being quiet, silence, social world, interaction rituals, everyday conversations

\section{INTRODUCTION}

Both the conversational analysis and the study of interactive rituals focus on recognizing the structures of daily conversations and defining social situations by participants of social interactions. It seems, however, that sociologists pay too

Kazimierz Wielki University in Bydgoszcz, Poland, E-MAIL: ola_nowakowska@op.pl. 
little attention to developing methods and techniques of research and detailed transcription of silence by participants of social interactions. The aim of the article is to pay attention to some problems connected with researchers' treating of meaningful silence ${ }^{2}$ (Kurzon, 1998, pp. 5-23) as an expression and means of expression of a social actor, just as important as the rest of speech content. Some social contexts and conditions of silence will be shown in various situations and social worlds, but silence is almost never an individual matter as it has a social dimension (Jaworski, 1993; 1997). Thus, at the beginning of this paper I want to highlight that sociologists cannot be satisfied only with identifying while research (both qualitative and quantitative) silent people, while analysing state that 'person A has been silent for 3 minutes' or that 'people B and C are mute respondents or participants of, e.g., meetings or sessions.'

At the beginning it is worth pointing that "talking about silence is only apparently a paradox. Each silence provokes speaking, asking questions. Seeing a silent person we wonder why he/she is silent and what he/she wants to express by the silence [...]. The motives of being silent are different and very often difficult to be read” (Gogolewski, 1984, p. 15) Izydora Dąmbska writes, "sometimes its sense is precise by the convention” (1975, p. 101).

The theoreticians do not define silence unambiguously. Both silence and being quiet are, according to Tomasz Rokosz, abstract notions. Silence, while remaining in opposition to language, is, however, subjective. Jolanta Rokoszowa says that "silence is a phenomenon inherent in language. It is its other side, background" (1999, p. 226). Being quiet will be understood rather as a lack of sound, a state, a phonetic category. On the other hand, silence will be, according to Izydora Dąmbska, "the expression and means of communication, 2) the tactical nature of the action, 3) the characteristic symptom, 4) the moral category, 5) the aesthetic category, 6) mystical category” (Rokosz, 2010, p. 18; Dąmbska, 1963, p. 73). In an article on 'Semiotic silence functions,' Dąmbska states that silence is the result of the activity of refraining from speaking. "For semiotics, silence is particularly interesting as an expression of conscious speech inhibition where the situation is predicted or even seems to demand it. Such silence can be called significant or signified in the strict sense" (1975, p. 95). According to the author, silence considered as a sign may be a symptom (e.g., for a doctor) or a signal if it is an element of the mystery: "silence comes after certain words of prayer [...] simultaneously regulates the manner of behaviour of the participants of the service” (1975, p. 98). However,

I would like to express my gratitude to Dr. Jerzy Kąkol, for inspirational talks about silence and for making me aware of the importance of the silence of the sick. 
from a sociological point of view, the most interesting will be the understanding of silence as a means of conveying information and "expressions calculated on the recipient in the context of language games," e.g., ignoring as written by Erving Goffman in his work 'Behaviour in public places' (2008, pp. 129-130). It is also used as a way to prevent confrontation (hiding your own opinion) (Rancew-Sikora, 2007, p. 81), masking, disinformation, secrecy, and "is an important tool of human activity in the fight or in collaboration with others. In this aspect, silence is also an interesting object of moral axiology" (Dąmbska, 1975, p. 101). The silence may be an expression of duty, heroism (interrogation of the heroes of the Underground State), suffering, surrender (silence of the persecuted), betrayal of one's own position - according to Dąmbska, "silence is a duty, a virtue, sometimes it is a misdemeanour” (1975, p. 103).

\section{'WHY ARE PEOPLE SILENT?' AN UNSOLVED SOCIOLOGICAL QUESTION?}

Kwiryna Handke starts her book entitled 'Sociology of Language' with a chapter entitled 'Silence in the Social Space.' It seems that the launch of the debate on this particular problem shows the great role of silence significant from the point of view of linguistic communication. I state that the study of everyday conversations, interactive rituals, and the appropriate (in this respect) analysis of focus studies without answering the question of why people are silent in a given social situation, does not give us an opportunity to know social groups or social worlds, understanding group mechanisms, social positions, power relations, and real opinions of members of social situations. Without the reason for silence, sociologists most probably do not meet the basic postulate of sociology - we do not explain or fully understand the phenomena studied.

While there are a lot of works on conversational analysis, discourse analysis, focus group interviews, it seems that the researchers themselves often stop identifying silent persons during the survey, e.g., during the observed situation (e.g., meetings) and recording the duration of silence. There is a lack of a serious debate among sociologists about the ways of addressing the causes of silence, how it can be understood, and the social context in which it is being applied. The question arises on how to, e.g., measure leaving something unsaid? It is not a new problem. In a study entitled 'Silence' Cyprian Kamil Norwid asked: "HOW IS IT THAT ONE PART OF SPEECH IS LEFT IN THE GRAMMAR OF ALL LANGUAGES? [...] This part is 'LEAVING SOMETHING UNSAID’” (original writing; Norwid after: Rokoszowa, 1999, p. 225). 
Of course, the rules of transcripts of conversations provide for recording with the appropriate symbols such situations as: "interruption of speech of another person, when the speaker falls silent due to the interference of another participant in the course of speech (interruption) [...] spontaneous repulsion of speech, abandonment of speech »in half-words«, sometimes in order to make auto correction, change of the word started or speech (cut-off) and breaks measured in seconds or parts of seconds” (Rancew-Sikora, 2007, pp. 37-38). In this article, I will try to show how serious this is a problem and how silence can be understood from the perspective of research conducted not only in the field of language sociology. It may be that the silence of individuals in different institutions results in the development and maintenance of organizational pathologies. In the absence of support for talking about difficult issues, consequently, "spiral of silence” (NoelleNeumann, 2004) and the "conspiracy of silence" can be used to incite violence, crime, such as scams and mobbing. A study conducted at Cornell University at the National Social Survey and published by the Harvard Business Review shows that employees are silent at work when they are afraid they will get into trouble and predict that their opinions will not change anything. They often use self-censorship, do not use constructive criticism because they are afraid of consequences and do not want to waste time communicating information on how to improve, prevent and solve problems, or identify the reasons for poor performance. (Detert, Burris, \& Harrison, 2012). Most likely, this is due to the belief that 'it will not change anything', 'no one is interested', which undoubtedly primes and legitimizes the status quo.

Research on the silence of employees in the context of knowledge management is also presented by Polish researchers Marta Moczulska and Janina Stankiewicz. Employees are most often silent on personal issues and on issues directly related to the organization and participation of employees, among which, according to the results of research by Frances Milliken, Elisabeth Morrison and Patricia Hewlin, the following are worth attention: competence of superiors/co-workers, and the development of the company, including 'making changes' (Moczulska \& Stankiewicz, 2008, pp. 142-143). Other causes of silence include fear of being the one who gives opinions that create problems and one that criticizes superiors, fear of destroying people's relationships, lack of sense of duty, resignation, fear of consequences (loss of work, lack of promotion), and co-workers ('driving someone in trouble'). It is also important to mention organizational culture which does not favour talking about problems. Below I present after Marta Moczulska and Janina Stankiewicz a table showing types of silence and speaking, taking into account motives and types of employee behaviour. 
Table 1. Types of employee behaviour (silence and speaking) and motives of behaviour

\begin{tabular}{|c|c|c|}
\hline & \multicolumn{2}{|c|}{ Types of behaviour } \\
\hline $\begin{array}{c}\text { Behavioural } \\
\text { motives }\end{array}$ & $\begin{array}{l}\text { The silence of the staff } \\
\text { (Deliberately hiding opinions, ideas } \\
\text { related to the performance of work / } \\
\text { organization) }\end{array}$ & $\begin{array}{l}\text { Speaking } \\
\text { (Conscious expression of ideas, } \\
\text { ideas related to performance / } \\
\text { functioning of an organization) }\end{array}$ \\
\hline Resignation & $\begin{array}{c}\text { Allowing silence } \\
\text { For example, retention of opinion as } \\
\text { a result of a sense of low efficiency } \\
\text { effect on the ability to make } \\
\text { a change }\end{array}$ & $\begin{array}{l}\text { Permissive voice } \\
\text { e.g., agreeing with the opinion of } \\
\text { the group, as a result of feeling no } \\
\text { change in the decision (majority) }\end{array}$ \\
\hline Fear & $\begin{array}{l}\text { Defensive silence } \\
\text { For example, not disclosing facts in } \\
\text { order to defend oneself (workplace, } \\
\text { prestige, perception by others) }\end{array}$ & $\begin{array}{c}\text { Defence voice } \\
\text { e.g., proposing decisions that focus } \\
\text { on others, in order to 'defend' } \\
\text { themselves }\end{array}$ \\
\hline $\begin{array}{l}\text { Feeling the } \\
\text { barrier of } \\
\text { cooperation }\end{array}$ & $\begin{array}{l}\text { Pro-social silence } \\
\text { For example, protecting public } \\
\text { knowledge that benefits the } \\
\text { organization }\end{array}$ & $\begin{array}{c}\text { Pro-social voice } \\
\text { For example, suggest constructive } \\
\text { ideas for changes that can benefit } \\
\text { your organization }\end{array}$ \\
\hline
\end{tabular}

Source: (Moczulska \& Stankiewicz, 2008, p. 144, after: Van Dyne, Ang, \& Botero, 2003, p. 1363).

\section{SOCIALISING TO SILENCE?}

In linguistics, silence is treated as a linguistic fact. From a sociologist's point of view, silence should be understood as expression and means of expression (Handke, 2008, p. 16), which is a message. The purpose of this article is to point out that a sociologist should try to find the answer to the questions: What can this message say? What sense do people give to silence? How do they read it? How is it valued? (Handke, 2008, p. 17) What emotions and thoughts does it express? With what intentions are people silent? Is silence integral, such as silence at the funeral or silent march? Or does it express a serious, long-lasting conflict ${ }^{3}$ or sometimes dramatic manifestation of disparities of power and even its abuse from the standpoint of a position, e.g., a formal one? Or perhaps silence is a result of fear (Wilkinson, 2008, pp. 856-883)? It is worth considering how this category should

\footnotetext{
3 "The silence on all important topics is not only a principle in the PRL but finally a second nature, degenerates people, makes them inhuman” (Kisielewski, 1996, p. 615, after: Jadacki, 1999, p. 18).
} 
be analysed with the use of sociological imagination in the context of historical and geographical conditions, both on a micro scale, as well as macro one. After all: "Silence participates in the whole cycle of social communication on the same level as speaking, expresses itself in various ways and in various forms. At the same time, the share of silence in individual situations and circumstances is not the same: in some cases it is equivalent to speaking, in others - it is only its background. But it is always present as a full-fledged social communication" (Handke, 2008, p. 38; Kenny, 2011).

From the point of view of sociology, it is important to recall that we learn to be silent as we learn to speak (Zerubavel, 2006). It is a process that is culturally and socially conditioned. This is due to the process of socialization "we begin to understand the meaning and meaning of intentional and situational silence, e.g., we are stigmatized for tattling (as in a poem 'Tattletale' by Brzechwa). As a consequence, we learn to be silent even when very important problems are concerned. Finally, we learn to use silence as a non-verbal but significant component of social communication" (Handke, 2008, p. 18). One of the places where we learn to keep silent is school. Roland Meighan describes strategies for survival in school: resignation and masquerade (false involvement) (1993, p. 78), and even resistance. The students are silent (do not express their opinions), pretending the teacher's appreciation to get a good grade, which is one of the elements of a hidden educational program.

Daniel J. Curran and Claire Renzetti recall Carol Gilligan's study of the socialization of girls to silence during adolescence. Consequently, for the sustenance or protection of their esteemed and highly esteemed interpersonal relationships, "girls [...] learn silence and gradually lose their former energy and vitality. They accept a situation where »to be with other people must be absent«. Girls of the richer social groups begin to talk quieter and modulate their voice, hence they are »accepted « by people from their immediate environment (e.g., boys, teachers, parents). Thus they do not close their way to social privileges, welfare and marriage” (2005, p. 159). Already in a previously published work entitled 'Sociology of Language’, Zbigniew Bokszański, Andrzej Piotrowski and Marek Ziółkowski wrote about language as an indicator of social position, as argued by their studies by Wilhelm Labov and Basil Bernstein (1977, pp. 94-131).

Randall Collins, creator of interactive ritual theory, further states that "when individuals have the power and prestige (forms of generalized cultural capital), they have the ability to control the rhythm of interaction. When they say, others listen and respond with positive emotional signals, thus strengthening the cultural capital and emotional energy of a person with power and prestige” (Turner \& Stets, 
2009, p. 101). In Collins' theory, permission to speak and even to give orders and the compulsion of obedience and alienation is classically conditioned, which once again becomes an important argument for the special concern of scholars to take into account the question of silence in the unmasking of the asymmetric rules of rituals of power and status, rituals of showing respect, enforced rituals and ritually take over the order in the conversation (Collins, 2011, pp. 69, 84-93, 133-140; Warczok, 2011, pp. XIV-Xv). Undoubtedly, during these rituals we find evidence of the existence of a clear hierarchy: silence is the one which is lower in structure, which expresses the proverb: 'Children and fish have no voice.' "Individually expressed thoughts about speech, silence, being quiet, and their relationship are part of the general cultural and linguistic heritage of the community and at the same time derive from it, thus showing the established roles they play in a given social space" (Handke, 2008, p. 33).

Pierre Bourdieu considers silence one of the economics of higher and lower classes. The radical saving of the lower class language is, as described by Małgorzata Jacyno, in silence: Bourdieu's silence is labelled a strategy that protects the middle classes from compromise and the lower classes from exposing themselves to the laughter of their own world. Hence the silence becomes - as the author argues - a well-understood interest of the lower classes. It does not appear to be a rhetorical formula. In the strategy of silence one can perceive a specific interest in the lower classes if one takes into account what Bourdieu calls classless unconsciousness. Silence is not only Freud's symptom, but also a defence mechanism. Breaking the silence is for the 'sacrifice' identical to the end of the world; its world. But this specific anti-language, which is silence, affirms, upholds and 'calls' the difference between higher and lower classes. Lower classes - like Weber are 'disadvantaged'. Ultimately self-censorship - so Bourdieu defines the language of lower classes - turns out to be a strategy of saving one's own world and 'naming' its difference (Achino-Loeb, 2005, pp. 35-55). The distance between upper and lower classes is the distance between speech and silence (Jacyno, 1997, pp. 106-107).

Silence 'learned socially' is chosen as a form of expression (Goffman, 2000, pp. 80-99) also in other cases. I think it is worth mentioning situations such as silence in the perspective of expectations, silence as an expression of opportunism, false presentation (mystification), silence as a commodity for which to pay, silence as coercion in asymmetrical relations of power, silence of a person caught on a crime, silence in the family, silence in the situation of danger, silence of the sick and the dying, silence as a life-long commitment - such as the mystery of confession, or the silence of the profession - such as medical secrets. 


\section{SILENCE AS A VIRTUE}

Finally, I will refer to the phenomenon of institutional silence, given the importance and value of holiness, the sacrum silentium, which is in force in religious orders and seminaries, and during religious ceremonies (Janiec, 2012; Sielepin, 2012). Especially interesting is the silence of the clergy, which is treated as a choice, both institutional and spiritual. The theology of silence deserves a separate elaboration. However, the most important elements of the silence present in Christian spirituality, especially the monastic one, should be highlighted. It is worth stressing that research is also being carried out on silence in Chinese culture, Taoism, Buddhist, Zen meditation (Augustyniak, 2010; Wypych, 2010; Żak, 2010). ${ }^{4}$ At the time of writing this article, I reached four people who agreed to be informants (those who have direct access to closed institutions - male and female orders and seminaries). Their findings show that the sacrum silentium is respected in these institutions, so it is rather not a dead right. The silence in Christian spirituality is treated as a virtue that serves the moral good, the pursuit of spiritual perfection, and so is written in the various textbooks of the life of the ascetics, including the Benedictine Rule. ${ }^{5}$ It is advisable to avoid talking about many things and to love silence as a way to hear the voice of God. In some convents, there is the possibility of stopping to speak, a complete withdrawal from the religious community, vows of silence, and hermit life (Cheneviere, 1984) in the full sense of the word. Silence is understood as virtue also by the philosophers, with autotelic value. Hanna Buczyńska-Garewicz's work was devoted to silence and philosophy of speech: "In the conclusions of the Treaty, Wittgenstein uttered the famous saying: 'What cannot be said, you must be silent - or rather »it must be silent«” (Buczyńska-Garewicz, 2003, p. 24). He also raises the idea of an inexpressible, or mystical, ethical. "You cannot talk about what is not in the language, that is, in matters other than empirical, you must be silent” (Buczyńska-Garewicz, 2003, p. 25).

The need for silence in times when the characteristic condition is rather informative noise rather than focus, are expressed more and more often by secular retreats (e.g., Ignatian), involving a few days or a few weeks of silence. Of course, for a sociologist this kind of silence is methodological, perhaps a pre-doomed

"Before the soul begins to hear, a man must be dull to screams whispers, the trumpeting elephants, and the silvery buzz of the golden skylight. Before the soul begins to understand and remember, it must unite with the Silent Speaker, like a form that before it fills with the clay, unites with the mind of the potter. Only then will the soul hear and remember. Then also the inner ear will say THE VOICE OF SILENCE” (Blavatsky, 1996, p. 15).

5 See: Chapter 6. O cnocie milczenia, http://www.benedyktyni.pl/regula/roz1_22.htm; Chapter 42. O milczeniu po Komplecie, http://www.benedyktyni.pl/regula/roz38_73.htm. 
challenge! For example, due to ethical constraints. Perhaps in the study of silence should the limits of sociological cognition be established? How to study the silence of hermits, their meditations on sacred books? How to study the silence during religious rituals, such as meditation, adoration, contemplative and prayer silence? What are the implications for the participants? Are they silent because it beseems so? Because it is a fixed ritual? Or can they really enter into a dialogue with the deity? How to explore internal dialogue?

Finally, the following questions should be asked: How to investigate the role conflicts involved in the implementation of a silence order (e.g., the secret of confession) and the civic obligation to inform the relevant services about the crime or the protection of victims of prohibited acts? Are these social interaction studies? Probably yes. After all, a common observer may find that 'nothing happens' because 'nothing is heard'. Sociologist should answer the questions already asked. Perhaps this will require more in-depth observation, additional questions to the respondents during interviews, and perhaps the development of new research methods and techniques, but we certainly cannot be content with merely diagnosing a silent act. I rather think that exploring social spaces of silence is a great challenge faced by sociologists using the qualitative research methodology.

As I pointed out at the beginning, silence deserves special attention from sociologists. Perhaps it is this, sometimes even more than the words spoken by people that explains the social reality and attests to the truth about the structures, processes, and rules of social functioning.

\section{References:}

Achino-Loeb, M. (2005). The Currency of Power. New York: Berghahn Books.

Augustyniak, A. (2010). Użyteczność i skuteczność milczenia we wczesnym taoizmie. In:

B. Płonka-Syroka, \& K. Marchel (Eds.), Cisza i milczenie. Społeczno-kulturowe mechanizmy kreowania emocji (pp. 253-261). Wrocław: Oficyna Wydawnicza Arboretum.

Blavatsky, H.P. (1996). Głos ciszy. Warszawa: Wydawnictwo Ethos.

Bokszański, Z., Piotrowski, A., \& Ziółkowski, M. (1977). Socjologia języka. Warszawa: Wiedza Powszechna.

Buczyńska-Garewicz, H. (2003). Milczenie i mowa filozofii. Warszawa: Wydawnictwo IFiS PAN.

Cheneviere, L. (1984). Rozmowy o milczeniu. Kraków: Wydawnictwo Karmelitów Bosych.

Collins, R. (2011). Łańcuchy rytuałów interakcyjnych. Kraków: Zakład Wydawniczy Nomos.

Curran, D.J., \& Renzetti, C.M. (2005). Kobiety, mężczyźni i społeczeństwo. Warszawa: Wydawnictwo Naukowe PWN.

Dąmbska, I. (1963). Milczenie jako wyraz i jako wartość, Roczniki Filozoficzne KUL, 11(1), pp. 73-79. 
Dąmbska, I. (1975). O funkcjach semiotycznych milczenia. In: I. Dąmbska, Znaki i myśli. Wybór pism z semiotyki, teorii nauki i historii filozofii (pp. 93-104). Warszawa: Wydawnictwo Naukowe PWN.

Detert, J.R., Burris, E.R., \& Harrison, D.A. (2012). Obalanie mitów na temat milczenia pracowników, Harvard Business Review Polska, 3 listopada. Retrieved from: https://www. hbrp.pl/a/obalanie-mitow-na-temat-milczenia-pracownikow/4O6iuFRB

Goffman, E. (2000). Człowiek w teatrze życia codziennego. Warszawa: Wydawnictwo KR.

Goffman, E. (2008). Zachowanie w miejscach publicznych. Warszawa: Wydawnictwo Naukowe PWN.

Gogolewski, T. (1984). Wstęp. In: L. Cheneviere. Rozmowy o milczeniu. Kraków: Wydawnictwo Karmelitów Bosych.

Handke, K. (2008). Socjologia języka. Warszawa: Wydawnictwo Naukowe PWN.

Jacyno, M. (1997). Iluzje codzienności. O teorii socjologicznej Pierrèa Bourdieu. Warszawa: Wydawnictwo IFiS PAN.

Jadacki, J.J. (1999). O pojęciu milczenia. In: K. Handke (Ed.), Semantyka milczenia (pp. 17-32). Warszawa: Slawistyczny Ośrodek Wydawniczy przy IS PAN.

Janiec, Z. (2012). Konieczność, rodzaje i chwile milczenia we Mszy św., Anamnesis, 11(4), pp. 37-46. Retrieved from: http://www.kkbids.episkopat.pl/uploaded/a39/Anamnesis394aJaniec-Milczenie.pdf

Jaworski, A. (1993). The Power of Silence: Social and Pragmatic Perspectives. Newbury Parc: Sage Publications.

Jaworski, A. (1997). Silence: Interdisciplinary Perspectives. Berlin: Walter de Gruyter.

Kalinowska, M. (1989). Mowa i milczenie. Romantyczne antynomie samotności. Warszawa: Państwowy Instytut Wydawniczy.

Kenny, C. (2011). The Power of Silence: Silent Communication in Daily Life. London: Karnac Books.

Kurzon, D. (1998). Discourse of Silence. Amsterdam-Philadelphia: John Benjamins Publishing Co.

Meighan, R. (1993). Socjologia edukacji. Toruń: Wydawnictwo UMK.

Moczulska, M., \& Stankiewicz, J. (2008). Milczenie pracowników a zarządzanie wiedzą, Zeszyty Naukowe Wyższej Szkoły Ekonomiczno-Społecznej w Ostrołęce, pp. 141-146.

Noelle-Neumann, E. (2004). Spirala milczenia. Poznań: Zysk i S-ka.

Rancew-Sikora, D. (2007). Analiza konwersacyjna jako metoda badania rozmów codziennych. Warszawa: Wydawnictwo Trio.

Rokosz, T. (2010). Pojęcie “cisza” i “milczenie” w ujęciu kognitywnym - prolegomena. In:

B. Płonka-Syroka, \& K. Marchel (Eds.), Cisza i milczenie. Społeczno-kulturowe mechanizmy kreowania emocji (pp. 17-32). Wrocław: Oficyna Wydawnicza Arboretum.

Rokoszowa, J. (1999). Język, czas, milczenie. Kraków: Wydawnictwo PAN.

Sielepin, A. (2012). Milczenie w liturgii. Anamnesis, 12(44), pp. 74-81. Retrieved from: http:// www.kkbids.episkopat.pl/uploaded/a43/Anamnesis44-4bSielepin.pdf

Szuksztul, R. (2010). Cisza i milczenie w buddyzmie zen. In: B. Płonka-Syroka, \& K. Marchel (Eds.), Cisza i milczenie. Społeczno-kulturowe mechanizmy kreowania emocji (pp. 275283). Wrocław: Oficyna Wydawnicza Arboretum. 
Turner, J.H., \& Stets, J.E. (2009). Socjologia emocji. Warszawa: Wydawnictwo Naukowe PWN.

Van Dyne, L.V., Ang, S., \& Botero, I.C. (2003). Conceptualizing Employee Silence and Employee Voice as Multidimensional Constructs, Journal of Management Studies, 40(6), pp. 1359-1392. DOI: http://dx.doi.org/10.1111/1467-6486.00384

Warczok, T. (2011). Konflikt, rytuał, emocje - socjologia Randalla Collinsa. In: R. Collins, Łańcuchy rytuałów interakcyjnych (pp. IX-XxxiI). (Translated by K. Suwada). Kraków: Zakład Wydawniczy Nomos.

Wilkinson, I. (2008). W stronę socjologicznej konceptualizacji problemu lęku. In: P. Sztompka, \& M. Bogunia-Borowska (Eds.), Socjologia codzienności (pp. 856-883). Kraków: Wydawnictwo Znak.

Wypych, J. (2010). Sztuka milczenia w kulturze chińskiej. In: B. Płonka-Syroka, \& K. Marchel (Eds.), Cisza i milczenie. Społeczno-kulturowe mechanizmy kreowania emocji (pp. 245-252). Wrocław: Oficyna Wydawnicza Arboretum.

Zerubavel, E. (2006). The Elephant in the Room: Silence and Denial in Everyday Life. New York: Oxford University Press.

Żak, K. (2010). Cisza jako fenomen. Refleksje nad buddyjską medytacją zen. In: B. Płonka-Syroka, K. Marchel (Eds.), Cisza i milczenie. Społeczno-kulturowe mechanizmy kreowania emocji (pp. 263-274). Wrocław: Oficyna Wydawnicza Arboretum. 